Y. SHIN, K. A. WINANS, B. J. BACKES, S. B. H. KENT, J. A. ELLMAN, C. R. BERTOZZI* (UNIVERSITY OF CALIFORNIA, BERKELEY AND GRYPHON SCIENCES, SOUTH SAN FRANCISCO, USA)

Fmoc-Based Synthesis of Peptide- ${ }^{\alpha}$ Thioesters: Application to the Total Chemical Synthesis of a Glycoprotein by Native Chemical Ligation

J. Am. Chem. Soc. 1999, 121, 11684-11689.

\section{Total Chemical Synthesis of a Glycoprotein by Native Chemical Ligation}

Synthesis of glycopeptide- ${ }^{\alpha}$ thioester using the alkanesulfonamide "safety-catch" linker:<smiles>CCCNC(=O)CCCS(N)(=O)=O</smiles>

a) Fmoc-Gly-OH (4 equiv) PyBOP (3 equiv) DIEA (9 equiv)

DMF, $-20^{\circ} \mathrm{C}, 8 \mathrm{~h}$ to r.t.

b) SPPS using $N^{a}$-Fmoc-AA (11-23)

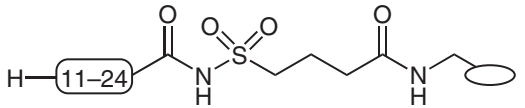

$\mathrm{DCC} / \mathrm{HOBt}$ in NMP

\section{Category}

Peptide Chemistry

\section{Key words}

native chemical ligation

thioesters

Fmoc chemistry

glycoproteins

alkanesulfonamides<smiles>CC(=O)NC(C(=O)O)C(C)OC1OC(COC(C)=O)(C(C)=O)C(C)(OC(C)=O)C1OC(C)=O</smiles>

$N^{a}$-Fmoc-Thr $\left(\mathrm{Ac}_{3}-\alpha-\mathrm{D}-\mathrm{GaINAc}\right)$

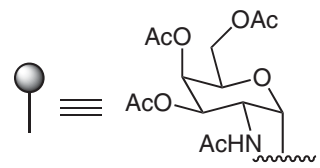

c) $N^{a}$-Fmoc-Thr(Ac $\left.{ }_{3}-\alpha-D-G a l N A c\right)$ (5 equiv) DIC (10 equiv), HOBt (10 equiv) DMF (30 min premix), 30 min

d) SPPS using $N^{\alpha}$-Fmoc-AA (2-9) $\mathrm{DCC} / \mathrm{HOBt}$ in NMP

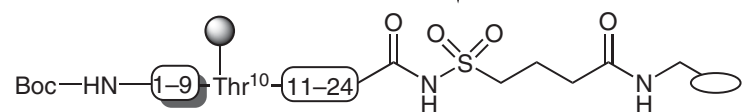
f) $\mathrm{ICH}_{2} \mathrm{CN}$, DIEA, NMP, $24 \mathrm{~h}$<smiles>CCCCNC(=O)CCCS(=O)(=O)N(CC#N)C(=O)c1ccc([R18](=O)c2ccc(NC(=O)OC(C)(C)C)cc2)cc1</smiles><smiles></smiles>

h) reagent $\mathrm{K}$ (TFA $(82.5 \%)$, phenol $(5 \%), \mathrm{H}_{2} \mathrm{O}(5 \%)$, thioanisole (5\%), ethanedithiol $(2.5 \%), 4 \mathrm{~h}$

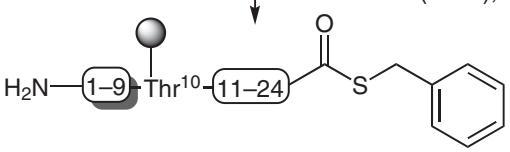

Significance: The authors have developed a new approach for the synthesis of unprotected ${ }^{\alpha}$ thioesters by using Fmoc-based solid-phase peptide synthesis and have demonstrated its utility in the total synthesis of a glycosylated protein, the antimicrobial O-linked glycoprotein diptericin, by the native chemical ligation method. This method utilizes an alkanesulfonamide 'safety-catch' linker, which circumvented the problems associated with the incompatibility of glycosidic linkages with Boc chemistry and of thioesters with Fmoc chemistry.

SYNFACTS Contributors: Hisashi Yamamoto, Manthena Chaithanya Synfacts 2019, 15(04), 0455 Published online: 19.03.2019 DOI: 10.1055/s-0037-1612281; Reg-No.: H01119SF
Comment: The C-terminal residue of the peptide is attached to the resin through an acid- and basestable $\mathrm{N}$-acyl sulfonamide linkage. After peptide synthesis, the sulfonamide is activated by cyanomethylation and then cleaved with a thiol nucleophile. This general synthetic approach permits access to unprecedented quantities of homogeneous glycoproteins. 